\title{
CONSTATAÇ̃̃o DE Xylella fastidiosa EM PECÍOLOS E HIPOCOTILOS DE CAFEEIRO COM SINTOMAS DE MANCHA MANTEIGOSA
}

\author{
Report of Xylella fastidiosa in petioles and hypocotyls of coffee plants with \\ symptoms of Buttery spot
}

\author{
Severina Rodrigues de Oliveira Lins ${ }^{1}$, Mário Sobral de Abreu², Eduardo Alves ${ }^{3}$, \\ Juliana Franco Barbosa ${ }^{4}$, Ricardo Magela de Souza ${ }^{5}$
}

\begin{abstract}
RESUMO
A mancha manteigosa tem afetado um grande número de plantas de cafeeiro em condições de campo. Sua causa tem sido atribuída a Colletotrichum gloeosporioides, entretanto a sintomatologia da doença na folha não tem sido reproduzida. Neste estudo, relata-se pela primeira vez a associação de Xylella fastidiosa, agente da atrofia dos ramos de cafeeiro, com pecíolo de folhas e hipocótilos obtidos a partir de sementes de plantas com sintomas da mancha manteigosa, através de estudos ultra-estruturais em Microscópio Eletrônico de Varredura (MEV), bem como por PCR (Polymerase Chain Reaction). Para o estudo foram realizados três ensaios. No primeiro, coletaram-se folhas com sintomas de mancha manteigosa e assintomáticas em duas localidades as quais foram preparadas para MEV. No segundo, pecíolos de 40 plantas sintomáticas e 40 assintomáticas foram coletados no campo experimental de café da UFLA. Os Pecíolos das folhas foram cortados e macerados para extração do DNA e analisados por PCR. Quatro pecíolos de cada uma destas amostras (plantas com e sem sintomas) também foram preparados para MEV. Em um terceiro ensaio, sementes obtidas de plantas com sintomas de mancha manteigosa, foram semeadas em bandejas de isopor contendo substrato Plantmax ${ }^{\circledR}$. As bandejas permaneceram em câmara de crescimento e aos 30,60 e 90 dias, após a semeadura, foram coletados hipocótilos para preparação e observação em MEV. Inicialmente uma bactéria semelhante à Xylella foi encontrada nos vasos do xilema de plantas sintomáticas das duas localidades estudadas. Pela análise por PCR constatou-se $X$. fastidiosa em $34 \%$ das plantas com sintoma da doença e 9,3\% nas sem o sintoma da mancha manteigosa. Pecíolos de plantas Xylella positivas por PCR apresentaram obstrução dos vasos do xilema pelas bactérias. Das quatro plantas negativas por PCR, apenas uma teve o pecíolo com vasos obstruídos pela bactéria quando analisados em MEV. Em hipocótilos analisados em MEV verificaram-se células bacterianas semelhantes à X. fastidiosa nos vasos do xilema aos 60 e 90 dias após semeadura. Esse é o primeiro relato da associação de $X$. fastidiosa a pecíolos e hipocótilos de cafeeiros expressando sintomas de mancha manteigosa.
\end{abstract}

Termos para indexação: Mancha manteigosa, Xylella fastidiosa, microscopia eletrônica de varredura, PCR.

\section{ABSTRACT}

Buttery spot has greatly affected coffee plants in field conditions. Its cause has been attributed to Colletotrichum gloeosporioides. However, its symptoms in leaves have not been reproduced. In this study we reported for the first time the presence of X. fastidiosa, causal agent of the coffee atrophy in petiole and hypocotyls from coffee plants with buttery spot through PCR and ultrastructural studies by scanning electron microscopy (SEM). In this study three trials were developed. In the first we collected leaves from plant with and without buttery spot symptoms in two places which were prepared for SEM. In the second petioles of 40 symptomatic and 40 asymptomatic leaves were collected in a coffee experimental field of Federal University of Lavras. Petiole from these leaves were cut and macerated for DNA extraction and analyzed by PCR. Four petioles of each sample (plants with and without symptoms) were prepared for SEM. In a third trial, seeds from plants with battery spot were sowed in foam trays with Plantimax® substrate. The trays stayed in a growth chamber and after 30,60 and 90 days of the germination hypocotyls were collected for preparation and observation in SEM. Initially a bacterium similar to X. fastidiosa was found in vessels of symptomatic plants studied. Through the analysis by PCR we verified X. fastidiosa in $34 \%$ of plants with the disease symptoms and 9,3\% in those without symptom of buttery spot. Petioles of positives Xylella plants by PCR presented obstruction of vessels of xylem by bacteria. Out of four PCR-negatives plants, one had petioles with vessels clogged by bacteria when analyzed by SEM. In analyzed hypocotyls with SEM were observed bacterial cells like X. fastidiosa in xylem vessels at 60 and 90 days. This is the first report of the colonization of X. fastidiosa in coffee plant petiole and hypocotyls of seeds of plants expressed buttery spot symptoms.

Index terms: Buttery spot, Xylella fastidiosa, Scanning electron microscopy, PCR.

(Recebido em 30 de novembro de 2006 e aprovado em 8 de maio de 2007)

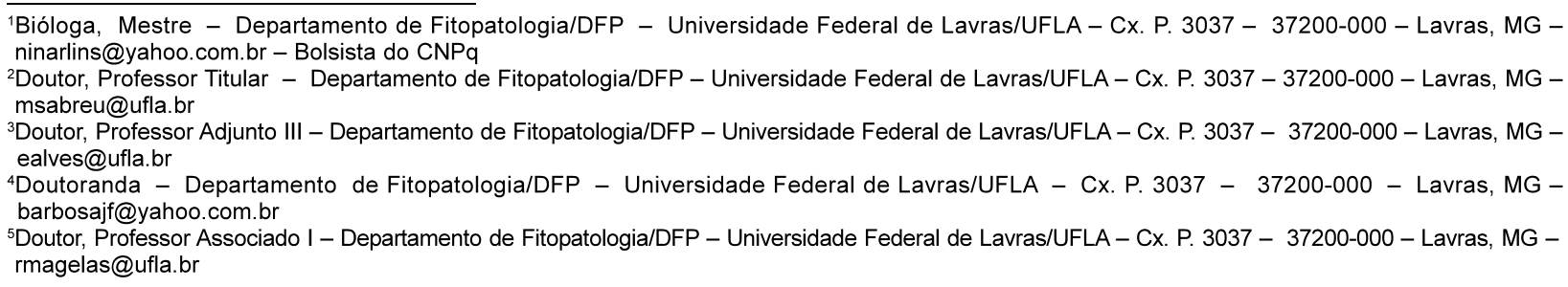

Ciênc. agrotec., Lavras, v. 32, n. 1, p. 42-47, jan./fev., 2008 


\section{INTRODUÇÃO}

A mancha manteigosa é uma doença do cafeeiro (Coffea arabica L.) que ocorre em alguns estados brasileiros e foi estudada por vários pesquisadores (DORIZZOTO \& ABREU, 1993; FERREIRA, 2004; OROZCO, 2003). Colletotrichum gloeosporioides Penz. tem sido referido como sendo o agente etiológico da doença (OROZCO, 2003). No entanto, trabalhos realizados com esse patossistema não conseguiram reproduzir os sintomas foliares característicos da doença.

Em trabalhos preliminares utilizando a microscopia eletrônica de varredura (MEV) verificou-se uma alta frequiência de bactérias semelhantes à Xylella fastidiosa (WELLS et al., 1987) obstruindo os vasos do xilema de pecíolos de folhas com sintomas da mancha manteigosa. Pecíolos de folhas são as partes das plantas mais utilizadas em trabalhos de levantamento de Xylella, (BARBOSA, 2003; BERETTA et al., 1997; HOPKINS, 1981; LIMA et al., 1998; RAJU et al., 1982) por ser a região com maior acúmulo da bactéria. X. fastidiosa foi detectada pela primeira vez em cafeeiro, no qual causa a atrofia dos ramos (PARADELA FILHO et al.), em 1995, no estado de São Paulo. A doença afeta desde mudas no viveiro, de três a quatro pares de folhas, até plantas adultas. Os sintomas visuais são folhas pequenas, verdes claras ou amareladas, com característica semelhante à deficiência de zinco, internódios curtos, redução do crescimento da planta, folhas mais velhas podendo apresentar queima nos bordos e no ápice. Com o ataque intenso ocorre senescência foliar precoce e, posteriormente, morte de ramos, tanto da haste principal como de ramos laterais, podendo ocorrer definhamento e morte do cafeeiro (PARADELA FILHO, 1998). Admite-se ainda a ocorrência de estresse hídrico devido à colonização e entupimento dos vasos xilemáticos pela bactéria (GOODWIN et al., 1988).

Objetivou-se neste trabalho verificar a presença da bactéria $X$. fastidiosa em pecíolos de folhas de plantas de café com mancha manteigosa através de estudos ultraestruturais em Microscópio Eletrônico de Varredura e por PCR, bem como em hipocótilos obtidos a partir de sementes colhidas em plantas de cafeeiro, com sintomas da doença.

\section{MATERIAL E MÉTODOS}

Para o desenvolvimento do estudo foram realizados três ensaios:

Primeiro ensaio: constatação da presença de $X$. fastidiosa em plantas de café com sintomas de mancha manteigosa.

Foram coletadas, aleatoriamente, folhas de plantas de café da cv Catucaí Vermelho, com sintomas típicos de mancha manteigosa, no campo experimental da UFLA e no Município de Carmo de Minas - MG. As folhas foram lavadas em água corrente, secas com papel de filtro e os pecíolos cortados, utilizando-se tesoura desinfetada com álcool 70\%, (fragmentos de um centímetro) e preparados para MEV.

\section{Preparação e observação das amostras em microscópio eletrônico de varredura}

Esse ensaio foi realizado no Laboratório de Microscopia Eletrônica e Análise Ultra-estrutural (LME) no Departamento de Fitopatologia da Universidade Federal de Lavras, MG.

Os pecíolos foram colocados em microtubos com capacidade para 1,5mL, contendo fixador Karnovisksy até cobrir as amostras e levados para geladeira por um período mínimo de 24 horas. Após, esses foram retirados do fixador e transferidos para glicerol $30 \%$ por 30 minutos. Em seguida, imersos em recipiente plástico contendo nitrogênio líquido e cortados com bisturi sobre uma placa de metal, imersa em um recipiente plástico, também contendo nitrogênio líquido. Seccionados transversalmente, as amostras (aproximadamente 15 secções) foram colocadas em microtubos contendo água destilada. Posteriormente, foram imersas em tetróxido de ósmio $1 \%$ em tampão por duas horas à temperatura ambiente. Subseqüentemente as amostras foram lavadas com água destilada por três vezes e desidratadas em uma série de acetona $(25 \%, 50 \%, 75 \%, 90 \%$ - 10 minutos cada e $100 \%$, por três vezes de 10 minutos). Em seguida, levadas ao aparelho de ponto crítico Balzers CPD 030, para substituição da acetona por $\mathrm{CO}_{2}$ com o objetivo de completar a secagem. Sem umidade, as amostras foram cuidadosamente montadas em "Stubs" (cilindro de alumínio com $12 \mathrm{~mm}$ de diâmetro, coberto com fita de carbono para aderência das amostras) e submetidas à metalização com ouro, no vaporizador Balzers SCD 050, para aumentar a condutividade dos elétrons no momento das análises com MEV Leo Evo 40.

Segundo ensaio: análise do pecíolo de folhas com sintomas de mancha manteigosa por PCR e MEV

As folhas para análise por PCR foram coletadas na lavoura da UFLA, a mesma daquelas analisadas em MEV. Coletaram-se 40 folhas de plantas com e 40 sem sintomas de mancha manteigosa, sendo 5 folhas de cada planta, as quais foram acondicionadas em sacos de papel, identificadas e levadas para o Laboratório de Diagnose e Controle de Enfermidades de Plantas do Departamento de Fitopatologia da UFLA. 


\section{Análise dos pecíolos por PCR}

Para a extração do DNA em pecíolos, seguiu-se a metodologia descrita por Minsavage et al. (1994), adaptada por Pinto \& Leite Júnior (1999) para cafeeiro. A visualização do produto da PCR foi feita em gel de agarose a $0,9 \%$, diluído em tampão TBE 0,5X (Solução estoque 10X 108g Tris $89 \mathrm{mM}, 55 \mathrm{~g}$ ácido bórico $89 \mathrm{mM}$, e EDTA 0,5 M em pH 8,0 ), corado com brometo de etídio. Para as amostras positivas foi repetida a reação de PCR para confirmação do resultado.

\section{Análise das amostras dos pecíolos por PCR e MEV}

Quatro pecíolos de cada uma das amostras (plantas com e sem sintomas) utilizados na análise de PCR, também foram preparados para MEV, seguindo metodologia descrita acima.

Terceiro ensaio: observação dos tecidos de hipocótilos obtidos de sementes de plantas, com mancha manteigosa, em MEV.

Para obtenção dos hipocótilos, sementes de plantas com sintomas da doença foram coletadas nos Campos Experimentais de Café da UFLA e do IAPAR, Londrina, PR e em Carmo de Minas. Essas foram plantadas em bandejas de isopor contendo substrato Plantmax ${ }^{\circledR}$ e mantidas protegidas em câmara de crescimento a $27 \pm 2^{\circ} \mathrm{C}$ por 120 dias e umidade relativa, variando de 70 a $85 \%$. Aos 30 dias foram coletados cinco hipocótilos de cada lote com $2 \mathrm{~cm}$ de comprimento e fixados para análise em microscópio eletrônico de varredura conforme metodologia descrita acima para os pecíolos. Outras coletas foram realizadas aos 60 e 90 dias quando já havia se formado o primeiro e segundo pares de folhas.

\section{RESULTADOS E DISCUSSÃO}

Constatação da presença de $X$. fastidiosa em plantas de café com sintomas de mancha manteigosa.

Em todos os pecíolos de plantas com sintomas de mancha manteigosa tanto as coletadas no Campo Experimental da UFLA quanto aquelas de Carmo de Minas, foi verificada a presença de bactéria em vasos do xilema, (Figuras 1B e 1C) formando agregados. Essas células bacterianas observadas em plantas sintomáticas apresentavam forma de bastonete, alongadas, envolvidas em substâncias extra-celulares (Figura 1B), com características similares à descrita para $X$. fastidiosa (BRLANSKY et al., 1992). De acordo com Costerton \& Irvin (1981) a agregação da bactéria parece estar ligada à liberação de substâncias extra-celulares que assemelham- se quimicamente aos polissacarídeos que constituem o glicocálix, o qual é responsável pela adesão de outras células bacterianas às células vizinhas. Esta substância extra-celular, também chamada de goma fastidiana, (Figura 1B), provavelmente produzida pelas próprias células (ALVES, 2003), também verificada em outros estudos (FRY \& MILHOLLAND, 1990; RAJU \& WELLS, 1986), tem sido importante para a identificação de X. fastidiosa em tecidos do xilema de plantas.Células bacterianas não foram constatadas em pecíolos de plantas adultas, sem sintomas da mancha manteigosa, nos campos amostrados (Figura 1A).

Foram também observados dois ou mais indivíduos alinhados longitudinalmente (Figura 1D) indicando que as bactérias se alongam durante as divisões celulares, o que explica a observação de indivíduos bem maiores em relação a outros da mesma colônia. Lima et al. (1998) também constataram esse fato em seus estudos sobre a clorose variegada dos citros.

\section{Análise do pecíolo de folhas com sintomas de mancha manteigosa por PCR e MEV}

Um dos métodos mais seguros para detecção de $X$. fastidiosa é através da amplificação do seu DNA pela reação da polimerase em cadeia, (METHA et al., 2000; POOLER \& HARTUNG, 1995). Os "primers" utilizados nesse estudo amplificaram um fragmento de 733 pares de base (pb), presente no controle positivo (folha de café com sintoma de internódios e folhas curtas) e colônia pura de $X$. fastidiosa, porém ausente nos controles negativos (planta de cafeeiro sem sintomas de Xylella). Assim as amostras que apresentaram o fragmento de $733 \mathrm{pb}$ amplificado foram consideradas positivas para $X$. fastidiosa. Verificou-se que amostras tanto de plantas com sintomas como sem o sintoma da mancha manteigosa foram positivas. Das 40 plantas com sintomas, $34 \%$ foram positivas para Xylella; das plantas assintomáticas $9,3 \%$ revelaram-se positivas (Figura 2A). As amostras positivas foram confirmadas em outra reação (Figura 2B).

Paralelamente às coletas para análise por PCR foram escolhidos pecíolos de oito folhas (4 sadias e 4 doentes), ao acaso, para preparação para MEV objetivando a análise interna dos vasos do xilema e comparação com os resultados da PCR. As amostras positivas para PCR, quando analisadas ultraestruturalmente, confirmaram a presença da bactéria. Das quatro amostras negativas para PCR três não continham células bacterianas nos vasos do xilema, quando analisada ao MEV; na outra amostra foram constatadas células bacterianas nos vasos do xilema. O fato de a bactéria estar presente em uma parte e ausente 

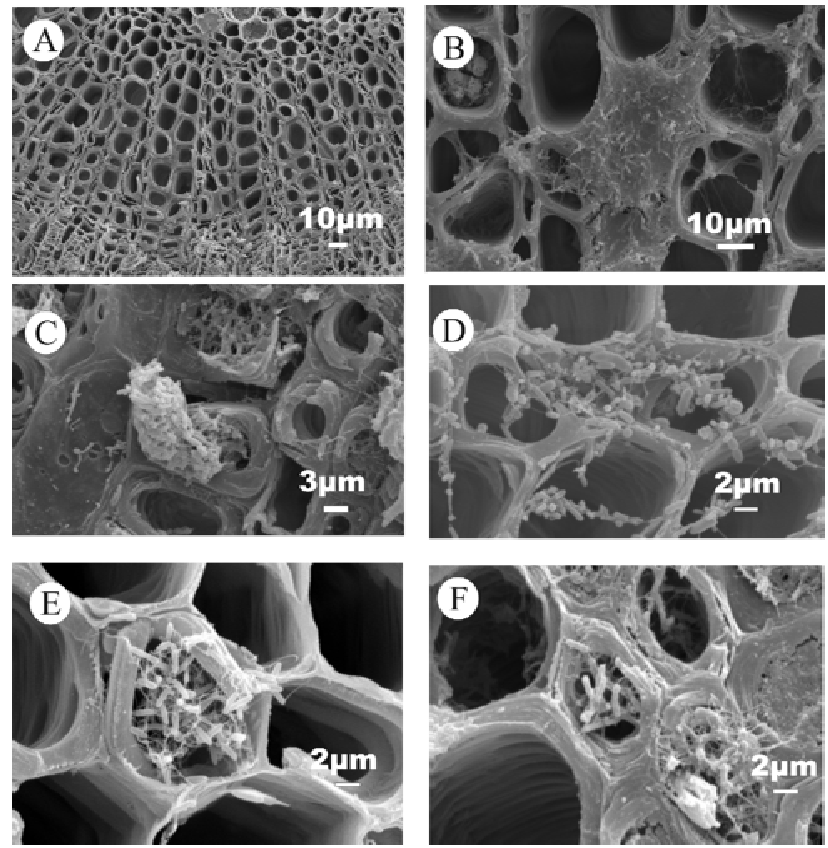

Figura 1 - Eletromicrografia de varredura mostrando cortes de pecíolos de folhas de plantas de cafeeiro com sintomas de mancha manteigosa apresentando $X$. fastidiosa colonizando vasos do xilema. A) Pecíolo de folha de planta sadia B) Pecíolo de folha de planta doente evidenciando obstrução dos vasos C) Células bacterianas envolvidas na goma fastidiosa D) Células bacterianas em diferentes tamanhos evidenciando o alongamento durante o crescimento. E) $X$. fastidiosa no xilema de hipocótilo de plântula de cafeeiro crescido de sementes de plantas com sintomas de mancha manteigosa F) Detalhe de colônia bacteriana no xilema de hipocótilo.
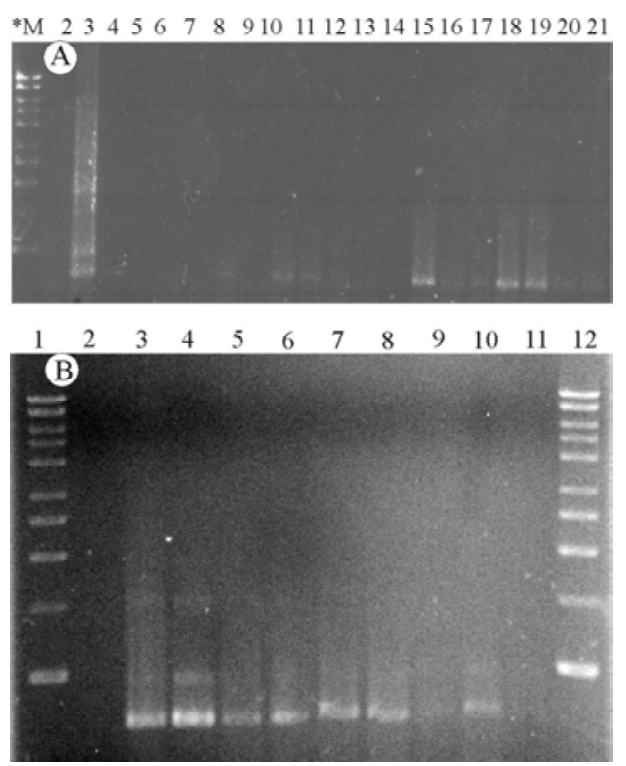

Figura 2 -A) Gel de agarose de produtos amplificados por PCR do DNA extraído de pecíolos de folhas de cafeeiro: M) marcador, 2) controle negativo - água, 3) controle positivo - Xylella fastidiosa, 4, 5, 6, 7, 8, 9, 11, 12) Plantas sadias, 10, 15, 17, 18, 19, 20, 21) Plantas com MM. B) Gel de agarose de produtos amplificados por PCR do DNA extraído do pecíolo de folhas de plantas de cafeeiro positivas no primeiro gel: 1 e 12) marcadores, 2 e 11) controles negativos, 3) controle positivo e 4-10) plantas com MM positivas para X. fastidiosa em A. Banda $733 \mathrm{~Kb}$. 
em outra na mesma planta, pode ser explicado por $X$. fastidiosa não apresentar uma distribuição uniforme nos vasos do xilema do pecíolo, como observado por Alves et al. (2004). Os resultados da presente pesquisa reforçam os observados por Takatsu et al. (2001), que a concentração de $X$. fastidiosa no extrato do xilema varia muito entre os ramos coletados da mesma planta e entre as diferentes partes do mesmo ramo. Yorinori et al. (2003) observaram distribuição não uniforme de $X$. fastidiosa nos tecidos da mesma planta de café quando comparando dois métodos de detecção (imunofluorescência indireta e DAS-ELISA). Isso pode colaborar para explicar os resultados da presente pesquisa, revelados após comparação entre os dois métodos estudados.

Observação dos tecidos de hipocótilos obtidos de sementes de plantas com mancha manteigosa em MEV.

Nas análises realizadas em hipocótilos de plântulas obtidos a partir de sementes de plantas, com sintomas de mancha manteigosa, foram verificadas células bacterianas semelhantes à $X$. fastidiosa em todas as amostras (Figuras $1 \mathrm{E}$ e 1F), demonstrando que essa bactéria também é disseminada pelas sementes. Embora Yorinori et al. (2003) tenham constatado a bactéria em frutos e plântulas de cafeeiro plantadas em campo, esta é a primeira constatação de transmissibilidade pela semente.

A associação desses dois organismos, em cafeeiro, expressando sintomas da mancha manteigosa ainda não havia sido relatada. Isso sugere que a mancha manteigosa em folhas pode ter etiologia complexa ocasionada por $C$. gloeosporioides e $X$. fastidiosa, os quais podem interagir através de enzimas, toxinas ou metabólitos, mesmo tendo sítios de colonização diferentes. A presença da bactéria em tecidos com mancha manteigosa pode ainda não ter sido detectada por causa dos métodos de isolamento utilizados até o momento, pois $X$. fastidiosa necessita de meio de cultura especial e o estudo ultra-estrutural de plantas com mancha manteigosa ainda não ter sido realizado. Portanto, esse trabalho é pioneiro com relação à constatação $X$. fastidiosa associada à mancha manteigosa, sugerindo-se estudos posteriores nessa linha de pesquisa.

\section{CONCLUSÕES}

Xylella fastidiosa está presente no xilema de pecíolos de folhas de café com sintomas de mancha manteigosa;

X. fastidiosa é encontrada em hipocótilos de plântulas obtidas a partir de sementes de plantas com sintomas de mancha manteigosa.
Há uma variação da colonização de $X$. fastidiosa em ramos e entre ramos de uma mesma planta de cafeeiro.

\section{REFERÊNCIAS BIBLIOGRÁFICAS}

ALVES, E. Xylella fastidiosa: adesão e colonização em vasos do xilema de laranjeira doce, cafeeiro, ameixeira, fumo e espécies de cigarrinha vetoras e formações de biofilme sobre película de poliestireno. 2003. $121 \mathrm{f}$. Tese (Doutorado) - Escola Superior de Agricultura "Luiz de Queiroz", Universidade de São Paulo, Piracicaba, 2003.

ALVES, E.; MARUCCI, C. R.; LOPES, J. R. S.; LEITE, B. Leaf symptoms on plum, coffee and citrus and the relationship with the extent of xylem vessels colonized by Xylella fastidiosa. Journal of Phytopathology, Berlin, v. 152, n. 1, p. 1-7, Jan. 2004.

BARBOSA, J. F. Ocorrência e padrão espacial da atrofia dos ramos do cafeeiro (Xylella fastidiosa) nas regiões sul e Zona da Mata de Minas Gerais. 2003. 88 p. Dissertação (Mestrado em Fitopatologia) - Universidade Federal de Lavras, Lavras, 2003.

BERETTA, M. J. G.; BARTHE, G. A.; CECCARDI, T. L.; LEE, R. F.; DERRICK, K. S. A survey for strain of Xillela fastidiosa in citrus affected by citrus variegated chlorosis and citrus bligth in Brazil. Plant Disease, Saint Paul, v. 81, n. 10, p. 1196-1198, Oct. 1997.

BRLANSKY, R. H.; TIMMER, L. W.; LEE, R. F. Detection transmission of gram-negative xylem limited bacterium sharpshooters from a citrus grove in Florida. Plant Disease, Saint Paul, v. 96, n. 7, p. 590-592, July 1992.

COSTERTON, J. W.; IRWIN, R. T. The bacterial glycocalyx in nature and disease. Annual Review Microbiology, [S.l.], v. 35, p. 299-324, 1981.

DORIZZOTTO, A.; ABREU, M. S. Reação de plântulas e frutos verdes de cafeeiro (Coffea arabica L.) a Colletotrichum coffeanum NOAK e Colletotrichum gloeosporioides PENZ. Fitopatologia Brasileira, Brasília, v. 18, p. 285s, 1993. Resumo.

FERREIRA, J. B. Flutuação sazonal e associação de Colletotrichum gloeosporioides Penz. a diferentes órgãos e tecidos de cafeeiros (Coffea arabica L.). 2004. $90 \mathrm{f}$. Dissertação (Mestrado em Fitopatologia) - Universidade Federal de Lavras, Lavras, 2004. 
FRY, S. M.; MILHOLLAND, R. D. Multiplication and translocation of Xylella fastidiosa in petioles and stems of grapevine resistant, tolerant, and susceptible to Pierce's disease. Phytopathology, Saint Paul, v. 80, n. 1, p. 61-65, Jan. 1990.

GOODWIN, P. H.; DEVAY, J. E.; MEDEDTH, C. P. Roles of water stress andphitotoxin in the development of Pierce's diseases of the grapevine. Physiological and Molecular Plant pathology, Saint Paul, v. 32, n. 1, p. 1-15, Jan. 1988.

HOPKINS, D. L. Seasonal concentration of the Pierce's disease bacterium in grapevine stems, petioles and leaf veins. Phytopathology, Saint Paul, v. 71, n. 4, p. 415-418, Apr. 1981.

LIMA, J. E. O.; MIRANDA, V. S.; HARTUNG, J. S.; HARTUNG, J. S.; BRLANSKY, R. H.; COUTINHO, A.; ROBERTO, S. R.; CARLOS, E. F. Coffee leaf scorch bacterium: axenic culture, pathogeniticy, and comparison with Xylella fastidiosa of citrus. Plant Disease, Saint Paul, v. 82, n. 1, p. 94-97, Jan. 1998.

METHA, A.; LEITE JÚNIOR, R. P.; ROSATO, Y. B. Polymorphism of Xylella fastidiosa strains by RAPD-PCR and SDS-PAGE of proteins. Fitopatologia Brasileira, Brasília, v. 25, n. 4, p. 651-656, Sept. 2000.

MINSAVAGE, G. V.; THOMPSON, C. M.; HOPKINS, D. L.; LEITE, R. M. V. B. C.; STALL, R. E. Development of a polymerase chain reaction protocol for detection of Xylella fastidiosa in plant tissue. Phytopathology, Saint Paul, v. 84, n. 4, p. 456-461, Apr. 1994.

OROZCO, E. F. M. Caracterização morfológica, molecular, bioquímica e patogênica de isolados de Colletotrichum spp. associados ao cafeeiro em Minas Gerais e comparação com Colletotrichum kahawae. 2003. 147 f. Tese (Doutorado em Fitopatologia) - Universidade federal de Lavras, Lavras, 2003.

PARADELA FILHO, O. Xylella do cafeeiro não é a mesma da CVC. Coopercitrus Informativo Agropecuário, [S.1.], ano 12, n. 143, p. 20-21, 1998.
PARADELA FILHO, O.; SUGIMORI, M. H.; RIBEIRO, I. J. A.; GARCIA JÚNIOR, F. F.; RODRIGUES NETO, J. R.; BERIAM, L. O. S. Primeira constatação em cafeeiro no Brasil da Xylella fastidiosa causadora da clorose variegada dos citros. Laranja, Cordeirópolis, v. 16, n. 2, p. 135-136, jan. 1995.

PINTO, F. G. S.; LEITE JÚNIOR, R. P. Detecção de Xylella fastidiosa em Coffea spp. através de técnica de PCR. Fitopatologia Brasileira, Brasília, v. 24, p. 254s, 1999.

POOLER, M. R.; HARTUNG, J. S. Specific PCR detection and identification of Xylella fastidiosa strains causing citrus variegated chlorosis. Current Microbiology, New York, v. 31, n. 3, p. 377-381, Mar. 1995.

RAJU, B. C.; WELLS, J. M. Disease caused by fastidious xylem-limited bacterium. Plant Desease, Saint Paul, v. 70, n. 3, p. 182-186, Mar. 1986.

RAJU, B. C.; WELLS, J. M.; NYLAND, G.; BRLANAKY, H.; LOWE, S. K. Plum leaf scald: isolation, culture, and pathogenicity of the casual agent. Phytopathology, Saint Paul, v. 72, n. 11, p. 1460-1466, Nov. 1982.

TAKATSU, A.; SANTOS, M. R.; MALUF, R. C. Xylella fastidiosa do cafeeiro no Triângulo Mineiro e Alto Paranaíba. In: SIMPÓSIO DE PESQUISA DOS CAFÉS DO BRASIL, 2., 2001, Vitória, ES. Resumos... Vitória: Embrapa Café, 2001. p. 1234-1241.

YORINORI, M. A.; RIBAS, A. F.; UENO, B.; MASSOBA JÚNIOR, N. S. Detecção de Xylella fastidiosa em germoplasma de cafeeiro. Fitopatologia Brasileira, Brasília, v. 28 , n. 4, p. 427-430, jul./ago. 2003.

WELLS, J. M.; RAJU, B. C.; HUNG, H. Y.; WEISBERG, W. G.; MANDELCO-PAUL, L.; BRENNER, J. W. G.; MANDELCO-PAUL, L.; BRENNER, D. J. Xylella fastidiosa gen. nov., sp. nov: gram-negative, xylem-limited, fastidious plant bacteria related to Xanthomonas spp. International Journal of Systematic Bacteriology, London, v. 37, n. 2, p. 136-143, Feb. 1987. 